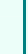

Published online: May 15, 2009

\title{
Fournier's Gangrene after Open Hemorrhoidectomy without a Predisposing Factor: Report of a Case and Review of the Literature
}

\author{
Guldeniz Karadeniz Cakmak Oktay Irkorucu \\ Bulent H. Ucan Kemal Karakaya \\ Department of Surgery, School of Medicine, Zonguldak Karaelmas University, \\ Kozlu-Zonguldak, Turkey
}

\section{Key Words}

Fournier's gangrene $\cdot$ Hemorrhoidectomy $\cdot$ Complication $\cdot$ Sepsis

\begin{abstract}
Fournier's gangrene (FG) is a fatal synergistic infectious disease with necrotizing fasciitis of the perineum and abdominal wall along with the scrotum and penis in men and vulva in women. An unpredictable case of FG two weeks after open hemorrhoidectomy in a previously healthy 55-year-old male is described. Full-thickness patchy skin necrosis of the perianal, perineal and scrotal region associated with rectal perforation was detected on admission. Prompt radical debridement together with aggressive fluid resuscitation and broad-spectrum antibiotic administration was initiated. Because of rectal involvement, diverting sigmoid colostomy was fashioned. The patient survived after two additional local debridements. Nevertheless, loss of sphincter function due to massive muscle destruction led to permanent colostomy. Our case together with others reported in the literature illustrates that, although rare, FG after open hemorrhoidectomy represents a life-threatening complication to otherwise healthy patients. The development of fever and urinary retention should draw the attention of the surgeon, even if the presentation is delayed. The current literature only briefly mentions the potential risk of FG after such a common surgical procedure. However, devastating complications occur more often than anticipated. This disastrous complication without predisposing factor is discussed along with a literature review.
\end{abstract}




\section{Introduction}

Fournier's gangrene (FG), defined as the necrotizing fasciitis of perineal, genital or perianal regions, remains a fulminant disease with considerable morbidity and mortality [1-3]. In 1883, Jean Alfred Fournier (1832-1914), a French venereologist, described a series of rapidly progressive gangrene of the penis and scrotum in five otherwise previously healthy young males without an apparent etiology, after which the condition is termed 'Fournier's gangrene' [4]. Since that time, several eponyms have been applied to these necrotizing soft tissue infections, describing the same entity with only historical importance, and hundreds of cases have been or are being reported in literature. In contrast to its original description, the disease is not limited to young males, nor is it independent of a causative etiology [5,6]. Currently, the etiopathogenesis of this fatal disease can usually be identified by means of causative factors, in addition to a predisposing cause $[7,8]$. Nevertheless, the actual incidence is yet to be discovered.

Anorectal, urogenital and local dermatologic sources are implicated in the pathogenesis of the disease, with a predominance of anorectal infections, namely perianal, perirectal and ischiorectal abscesses, anal fissure, and colonic perforations $[9,10]$. The most common predisposing factors are considered to be diabetes mellitus, steroid use, chronic alcoholism and advanced age [11-13]. The lethal clinical course usually begins with pruritus and discomfort of the affected area that is followed by a rapid erythema of the perineal region associated with systemic symptoms of sepsis, including fever, chills and hemodynamic instability in advanced circumstances. Factors associated with high mortality can be regarded as anorectal origin, extensive disease, commonly secondary to delayed diagnosis, advanced age, and clinical condition at presentation including either sepsis or septic shock with multiple organ dysfunctions. Despite the improvements for early diagnosis and refinements in surgical and medical therapeutic interventions, mortality rates remain high. Moreover, neither extended spectrum antibiotic administration nor advanced medical care seem to be efficient in providing accurate survival benefit [14]. The mainstays of effective management depend on early diagnosis and immediate radical debridement with or without colostomies, designed as an individualized therapy.

In spite of the mounting evidence supporting an anorectal origin as the initial source, FG is reported to be extremely rare following hemorrhoidectomy, particularly without predisposing conditions. Only eight cases of FG have previously been reported after hemorrhoidectomy [5,15-21]. This case is the second description of unforeseeable and unpredictable FG development after open hemorrhoidectomy in a patient otherwise healthy without a predisposing factor.

\section{Case Report}

A 55-year-old male patient was referred after local debridement with a two-day history of perianal pain, discharge, scrotal swelling, urinary retention and fever. Two weeks before admission he had undergone an open hemorrhoidectomy under local anesthesia in a private clinic on an outpatient basis. For the past one year he had periodically experienced bloody defecation without pain due to hemorrhoids and conservative means had failed. His medical history was otherwise unremarkable. The immediate postoperative course was uneventful. The operative data, including antibiotic prophylaxis and sterilization status, were missing. Nonsteroidal antiinflammatory medication were prescribed for postoperative analgesia that he used for three days. On the fifth postoperative day, increasing pain, subfebrile temperature and urinary retention led the patient to readmit himself to hospital. Rectal examination and urine analysis revealed neither abscess nor urinary tract infection. Nevertheless, extended spectrum antibiotics were prescribed and bed rest was advised. During the following week he 
experienced nothing but mild rectal pain. On the twelfth postoperative day, his complaints became irresistible and he presented to the hospital again with scrotal swelling, severe perianal pain and purulent discharge, after which local debridement was performed and the patient was transferred to our clinic $48 \mathrm{~h}$ later.

At the time of admission, the patient was septic with temperature $38.3^{\circ} \mathrm{C}$, heart rate 110 beats per minute and arterial tension $100 / 60 \mathrm{~mm} \mathrm{Hg}$. Physical examination revealed a large area of perianal cellulitis with patchy soft tissue necrosis over the scrotum, perineum and perianal region associated with purulent discharge, and several incisions performed for local debridement over the area were also detected (fig. 1). A perianal necrotizing fasciitis extending to the perineal and scrotal area was evident. The patient had major fecal incontinence with extensive edema and rectal digital examination was extremely painful. Laboratory values showed a white blood cell count of $21,000 / \mathrm{mm}^{3}$. Blood sugar values were consistently within normal ranges. As a consequence of his life-threatening status, the patient was taken to the operating room for radical debridement. Transurethral catheterization of the bladder yielded $300 \mathrm{ml}$ of clear urine. Multiple necrotic tissue samples and venous blood were cultured. The patient was placed on intravenous fluid resuscitation and imipenem was administered on an empirical basis. Rectal examination under general anesthesia revealed a massive involvement of the right lateral rectal wall with perforation and an abscess pouch reaching beyond the dentate line. The internal and external sphincter muscles were also cut off at this level. The necrotic soft tissue areas were widely debrided and a diverting sigmoid loop colostomy was fashioned from a stab wound in the same session (fig. 2). Testicular vascularization was normal (fig. 3 ). The wound is irrigated and covered with antibiotic dressings. Microbial culture showed a polymicrobial infection with Acinetobacter, Escherichia coli and Enterococcus. Blood cultures were negative. Histopathological examination was reported as necrotizing fasciitis. The postoperative course was unremarkable except that the patient required two additional local debridements on the first and second postoperative days, but never developed fever or systemic instability. The wound was bare of infection on postoperative day five and healthy granulation tissue developed with rapid contraction by means of regular dressings. Complete wound closure was achieved, without complication, by split-thickness skin grafting three weeks later. Colostomy closure was considered after the initial interventions. Nevertheless, the evaluation of anal sphincter function revealed no rectal tonus. Loop colostomy remained because the patient refused any further surgical interventions.

\section{Discussion}

Over the past century, after the definition of FG, a number of cases have been reported as a consequence of the surgical management of hemorrhoids, in some cases being fatal. The mortality rate associated with FG ranges from 3 to $38 \%$ [1]. The case of FG presented in this report is very unusual and unexpected, due to the absence of predisposing factors. FG is a well-defined clinical entity of synergistic, polymicrobial, necrotizing fasciitis of the perineum, scrotum, and penis, which is characterized by obliterative endarteritis of the subcutaneous arteries resulting in gangrene of the subcutaneous tissue and the overlying skin [7]. Depending on the origin of the infection, different types of organisms have been identified in patients with FG. Gram-negative enteric bacilli and Gram-positive cocci have been isolated in the majority of patients [22, 23].

Anorectal, urogenital and local dermatologic sources are implicated in the pathogenesis of the disease, with a predominance of anorectal infections, namely perianal, perirectal and ischiorectal abscesses, anal fissure, and colonic perforations $[9,10]$. Other colorectal causes of FG include colorectal carcinoma [24], anastomotic dehiscence [25], appendicitis [26], perforated sigmoid diverticulitis [27] and foreign body induced rectal perforation [28]. Despite the fact that the anorectal region is remarkably rich in bacterial flora, transanal interventions are considered to be free of infections and associated septic complications and commonly performed in outpatient clinics. Accordingly, the incidence of FG encountered due to anal procedures is extremely low $[6,14]$. Nevertheless, necrotizing perineal soft tissue infections requiring extensive surgical excisions have been reported after anal dilatation [29], hemorrhoidal banding [30] and rectal mucosal biopsy [31]. The case presented herein is a surgical disaster from two points of view: one is the 
unpredicted nature of septic complication in a previously healthy patient, and the other is the impending catastrophe preceded by delayed diagnosis.

Septic complications following both conservative and surgical treatment of hemorrhoids are rare, but may be catastrophic. The management of hemorrhoidal disease can be individualized according to the predominant symptoms and signs, and failure to appreciate this may increase the complication rate through inappropriate therapy. Septic complications following conservative and surgical treatments are probably underreported due to ethical or legal concerns. There is a wide spectrum of conservative and surgical treatment options for hemorrhoidal disease, including sclerotheraphy, band ligation, cryotherapy, open and closed hemorrhoidectomy, and stapled hemorrhoidectomy. Of the various methods available, open (Milligan-Morgan) hemorrhoidectomy remains one the most popular and widely performed interventions and many patients are suitable for ambulatory surgery $[32,33]$. This technique takes between 10 and $30 \mathrm{~min}$ and consists of the dissection, transfixion and excision of the piles with preservation of the intervening skin. Possible surgical complications include early or delayed postoperative hemorrhage, recurrence of hemorrhoids, and passive or urge incontinence, with an average complication rate of $<10 \%[34,35]$. Preserved skin areas can cause secondary stenoses of the anal canal due to adhesions [36].

The present report describes the second documented case of FG after open hemorrhoidectomy without a predisposing factor. In 2004, Lehnhardt et al. reported a case of FG after open hemorrhoidectomy in a previously healthy patient requiring subsequent abdominoperineal resection [5]. Nevertheless, there are several reports of FG after surgical treatment of hemorrhoids in the literature reviewed in table 1.

Unfortunately, most of the data including details about possible predisposing conditions, operative procedures and follow-up are not presented or different from the case presented herein.

The extension of infection in FG is dramatic and lethal in both nature and clinical course. The mainstay of treatment is prompt diagnosis and radical surgical debridement. Broad-spectrum antibiotic therapy should be instituted empirically, regardless of Gram stain and culture results [11]. The patients should receive antibiotic therapy, including regimens against aerobic and anaerobic microorganisms [1,7]. This treatment goal can be achieved by means of a penicillin-based drug in combination with metronidazole [18].

Although there was a median delay of two days after the onset of initial symptoms at the time of admission, the patient in this case report was treated successfully in accordance with current therapeutic concepts with aggressive hemodynamic stabilization, parenteral broad-spectrum antibiotic administration and urgent wide surgical excision to remove all devitalized tissue. Although some controversy exists regarding the need for fecal diversion, fashioning a sigmoid diverting colostomy from a stab wound without a median laparotomy was preferred at the same session due to the detection of rectal perforation. To mention the fact that the extent of the disease cannot be judged from the margins of cutaneous necrosis is of paramount importance. Radical excision of all necrotic tissues, regardless of the nature of the defect created, is strongly recommended [8]. The cutaneous involvement has been likened to 'the tip of the iceberg' as described previously [7]. The goal of surgical debridement is to remove all nonviable tissue, halt progression of infection and alleviate systemic toxicity. In previous studies, the propagation rate of fascial destruction in FG has been described to be as high as 2 to $3 \mathrm{~cm}$ per hour $[6,27,37]$. In this described case, the patient was referred to our clinic with a delay of $48 \mathrm{~h}$ that certainly extended the degree of tissue necrosis and contributed to systemic toxicity. If recognized and treated in an earlier fashion, the patient's tissue loss 
would have been smaller and morbidity would have been decreased. Therefore, the presence of unexpectedly severe pain, fever and urinary difficulties appear to be useful alarm symptoms for the presence of life-threatening FG following surgical treatment for hemorrhoids.

\section{Conclusions}

The case represented together with others reported in the literature serves to emphasize that, although extremely rare, disastrous complications do occur after surgical interventions for dealing with hemorrhoids, even in the absence of associated predisposing conditions. The current literature only partly mentions the potential risk of FG after commonly performed procedures for hemorrhoids, due to the rarity of reported cases. This is the second description of FG after open hemorrhoidectomy in a previously healthy patient. Nevertheless, the reason of this rarity should be clarified, as it might be attributed actually to the low incidence of FG development after hemorrhoidectomy or might reflect an underestimation of FG as a consequence of probably not reporting such cases, due to ethical or legal concerns. Whatever the reason, a delay in both diagnosis and surgical interventions are possibly the most crucial issues responsible for mortality, in addition to the presence of underlying diseases in FG. Surgeons should therefore retain a high index of suspicion when they encounter a patient returning troubled after such a procedure, even if the presentation is delayed by a number of days or weeks. Dealing with FG is a state of the art, prompt diagnosis and radical surgical debridement without hesitation in association with broad-spectrum antibiotic administration is of paramount importance for survival. 
Table 1. Fournier's gangrene after surgical treatment of hemorrhoids

\begin{tabular}{|c|c|c|c|c|c|c|}
\hline Author & Year & $\begin{array}{l}\text { Surgical } \\
\text { technique }\end{array}$ & $\begin{array}{l}\text { Predisposing } \\
\text { conditions }\end{array}$ & Culture & $\begin{array}{l}\text { Onset of } \\
\text { initial } \\
\text { symptoms }\end{array}$ & Mortality \\
\hline $\begin{array}{l}\text { Basoglu } \\
\text { et al. [17] }\end{array}$ & 1997 & open & $\begin{array}{l}\text { Diabetes } \\
\text { mellitus }\end{array}$ & $\begin{array}{l}\text { Escherichia coli, } \\
\text { Staphylococcus aureus, } \\
\text { Streptococcus anaerobius, etc. }\end{array}$ & 5 days & - \\
\hline $\begin{array}{l}\text { Cihan } \\
\text { et al. [15] }\end{array}$ & 1999 & open & $\begin{array}{l}\text { drug-induced } \\
\text { agranulocytosis }\end{array}$ & Pseudomonas aeruginosa & 72 hours & - \\
\hline $\begin{array}{l}\text { Bonner } \\
\text { et al. [16] }\end{array}$ & 2001 & stapler & none & $\begin{array}{l}\text { Propionibacterium acne, } \\
\text { Escherichia coli }\end{array}$ & 3 days & - \\
\hline $\begin{array}{l}\text { Atakan } \\
\text { et al. }[18]^{\text {a }}\end{array}$ & 2002 & $\begin{array}{l}\text { surgical } \\
\text { detail } \\
\text { unknown }\end{array}$ & $\begin{array}{l}\text { Diabetes } \\
\text { mellitus }\end{array}$ & $\begin{array}{l}\text { Escherichia coli, } \\
\text { Klebsiella pneumonia, } \\
\text { Pseudomonas aeruginosa, etc. }\end{array}$ & 3-14 days & $\begin{array}{l}\text { not } \\
\text { known }\end{array}$ \\
\hline $\begin{array}{l}\text { Lehnhardt } \\
\text { et al. [5] }\end{array}$ & 2004 & open & none & $\begin{array}{l}\text { Staphylococcus aureus, } \\
\text { Proteus mirabilis, } \\
\text { Bacteroides fragilis }\end{array}$ & 24 hours & - \\
\hline $\begin{array}{l}\text { Pessaux } \\
\text { et al. [21] }\end{array}$ & 2004 & stapler & none & $\begin{array}{l}\text { Escherichia coli, } \\
\text { Bacteroides fragilis, } \\
\text { Enterococci }\end{array}$ & 4 days & - \\
\hline $\begin{array}{l}\text { Gurfinkel } \\
\text { et al. [19] }\end{array}$ & 2005 & closed & not reported & Escherichia coli & 7 days & - \\
\hline $\begin{array}{l}\text { McCloud } \\
\text { et al. [20] }\end{array}$ & 2007 & stapler & none & Mixed coliform & 5 days & - \\
\hline
\end{tabular}

${ }^{a}$ The presented article is a case series, the data of the patient are not presented personally.

Fig. 1. Preoperative view demonstrates a large area of perianal cellulitis with patchy soft tissue necrosis over the scrotum, perineum and perianal region associated with purulent discharge and several incisions performed for local debridement.

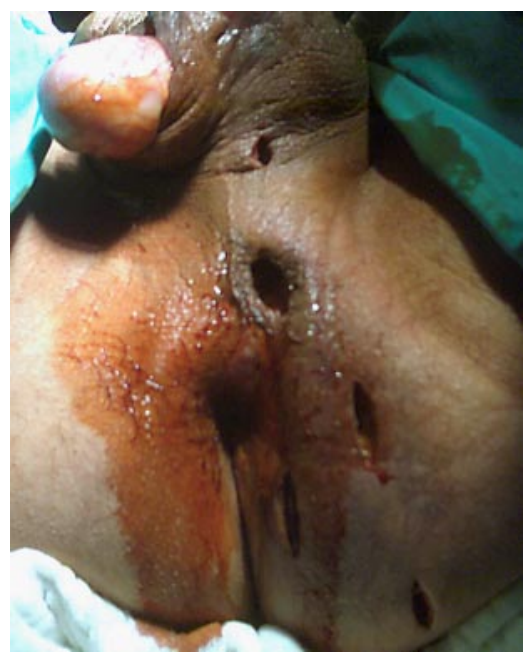


Case Reponts /h | Case Rep Gastroenterol 2009;3:147-155

Fig. 2. Wide surgical excision of all the gangrenous and devitalized tissue with the resultant extensive defect.

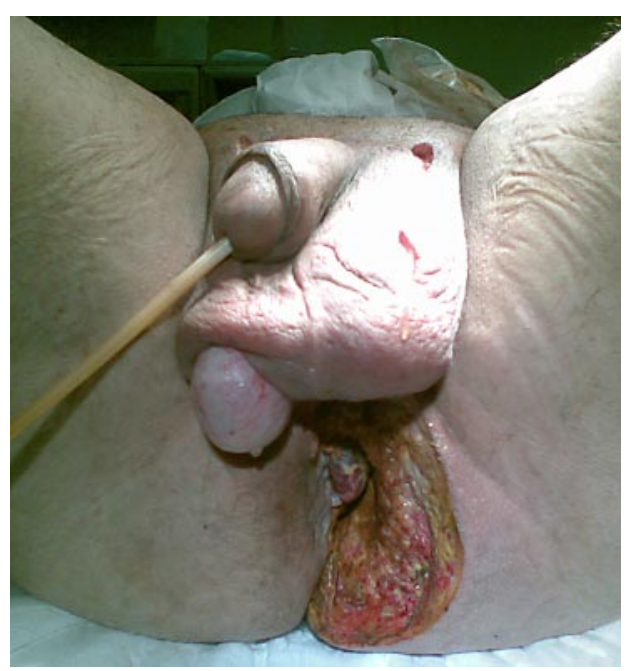

Fig. 3. The testis was not involved.

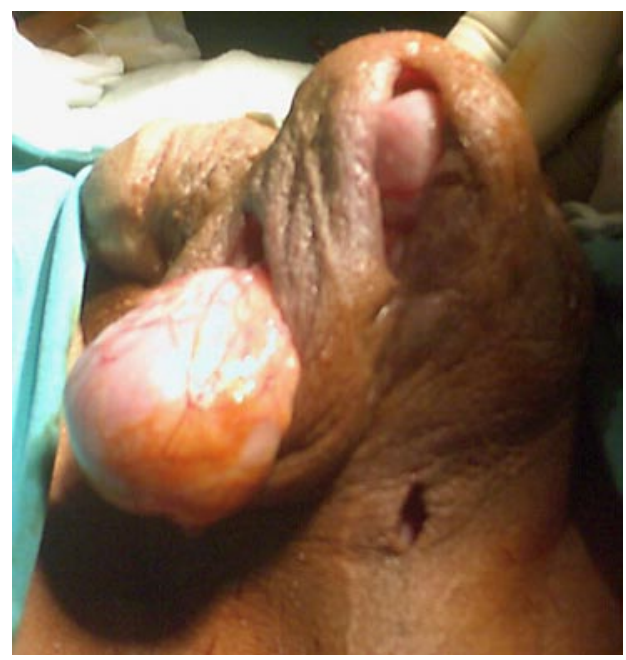




\section{References}

1 Morpurgo E, Galandiuk S: Fournier's gangrene. Surg Clin North Am 2002;82:1213-1224.

-2 Korkut M, Içöz G, Dayangaç M, Akgün E, Yeniay L, Erdoğan O, Cal C: Outcome analysis in patients with Fournier's gangrene: report of 45 cases. Dis Colon Rectum 2003;46:649-652.

-3 Yanar H, Taviloglu K, Ertekin C, Guloglu R, Zorba U, Cabioglu N, Baspinar I: Fournier's gangrene: risk factors and strategies for management. World J Surg 2006;30:1750-1754.

-4 Fournier JA: Jean-Alfred Fournier 1832-1914. Gangrène foudroyante de la verge (overwhelming gangrene). Sem Med 1883. Dis Colon Rectum 1988;31:984-988.

5 Lehnhardt M, Steinstraesser L, Druecke D, Muehlberger T, Steinau HU, Homann $\mathrm{HH}$ : Fournier's gangrene after Milligan-Morgan hemorrhoidectomy requiring subsequent abdominoperineal resection of the rectum: report of a case. Dis Colon Rectum 2004;47:1729-1733.

6 Kilic A, Aksoy Y, Kilic L: Fournier's gangrene: etiology, treatment, and complications. Ann Plast Surg 2001;47:523-527.

7 Vick R, Carson CC 3rd: Fournier's disease. Urol Clin North Am 1999;26:841-849.

$>8$ Basoglu M, Ozbey I, Atamanalp SS, et al: Management of Fournier's gangrene: review of 45 cases. Surg Today 2007;37:558-563.

-9aucks SS 2nd: Fournier's gangrene. Surg Clin North Am 1994;74:1339-1352.

10 Laor E, Palmer LS, Tolia BM, Reid RE, Winter HI: Outcome prediction in patients with Fournier's gangrene. J Urol 1995;154:89-92.

$>11$ Eke N: Fournier's gangrene: a review of 1,726 cases. Br J Surg 2000;87:718-728.

12 Taviloglu K, Gunay K, Ertekin C, et al: Necrotizing fasciitis: therapeutical modalities. Turk J Surg 1996;12:128-133.

13 Bugra D, Bozfakioglu Y, Buyukuncu Y, et al: Gangrène de Fournier. Etude analytique de six cas. J Chir 1990;127:115-116.

14 Yaghan RJ, Al-Jaberi TM, Bani-Hani I: Fournier's gangrene: changing face of the disease. Dis Colon Rectum 2000;43:1300-1308.

-15 Cihan A, Mentes BB, Sucak G, Karamercan A, Naznedar R, Ferahkose Z: Fournier's gangrene after hemorrhoidectomy: association with drug-induced agranulocytosis. Report of a case. Dis Colon Rectum 1999;42:1644-1648.

$\checkmark 16$ Bonner C, Prohm P, Storkel S: Fournier gangrene as a rare complication after stapler hemorrhoidectomy. Case report and review of the literature. Chirurg 2001;72:1464-1466.

17 Basoglu M, Gul O, Yildirgan I, Balik AA, Ozbey I, Oren D: Fournier's gangrene: review of fifteen cases. Am Surg 1997;63:1019-1021.

- 18 Atakan IH, Kaplan M, Kaya E, Aktoz T, Inci O: A life-threatening infection: Fournier's gangrene. Int Urol Nephrol 2002;34:387-392.

19 Gurfinkel R, Slovik Y, Glezinger R, Walfisch S: Fournier's gangrene as a delayed complication of closed hemorrhoidectomy. Harefuah 2005;144:394-396, 455-456.

20 McCloud JM, Doucas H, Scott AD, Jameson JS: Delayed presentation of life-threatening perineal sepsis following stapled haemorrhoidectomy: a case report. Ann R Coll Surg Engl 2007;89:301-302.

-21 Pessaux P, Lermite E, Tuech JJ, Brehant O, Regenet N, Arnaud JP: Pelvic sepsis after stapled hemorrhoidectomy. J Am Coll Surg 2004;199:824-825.

22 Chawla SN, Gallop C, Mydlo JH: Fournier's gangrene: an analysis of repeated surgical debridement. Eur Urol 2003;43:572-575.

23 Faucher LD, Morris SE, Edelman LS, et al: Burn center management of necrotizing soft-tissue surgical infection in unburned patients. Am J Surg 2001;182:563-569.

24 Dewire DM, Bergstein JM: Carcinoma of the sigmoid colon: an unusual cause of Fournier's gangrene. J Urol 1992;147:711-712.

25 Joo P, Peters WJ: Fournier's gangrene. Can J Surg 1985;28:180-182.

26 Gaeta M, Volta S, Minutoli A, Bartiromo G, Pandolfo I: Fournier gangrene caused by a perforated retroperitoneal appendix: CT demonstration. AJR Am J Roentgenol 1991;156:341-342. 
-27 Spirnak JP, Resnick MI, Hampel N, Persky L: Fournier’s gangrene: report of 20 patients. J Urol 1984;131:289-291.

28 Moreira CA, Wongpakdee S, Gennaro AR: A foreign body (chicken bone) in the rectum causing extensive perirectal and scrotal abscess: report of a case. Dis Colon Rectum 1975;18:407-409.

29 Gutmann H, Gonen P, Deutsch AA: Complications of anal dilatation for acute anal fissure (letter). Dis Colon Rectum 1989;32:545.

-30 Clay LD, White JJ, Davidson JT, Chandler JJ: Early recognition and successful management of pelvic cellulitis following hemorrhoidal banding. Dis Colon Rectum 1986;29:579-581.

-31 Cunningham BL, Nivatvongs S, Shons AR: Fournier's syndrome following anorectal examination and mucosal biopsy. Dis Colon Rectum 1979;22:51-54.

-32 Milligan ETC, Morgan CN, Jones LE, Officer R: Surgical anatomy of the anal canal and the operative treatment of haemorrhoids. Lancet 1937;13:1119-1124.

-33 Hunt L, Luck AJ, Rudkin G, Hewett PJ: Day-case haemorrhoidectomy. Br J Surg 1999;86:255-258.

-34 Herold A, Kirsch JJ: Differential surgical therapy in hemorrhoids. Kongressbd Dtsch Ges Chir Kongr 2001;118:315-318.

35 Winkler R: Hemorrhoids. On the evaluation of different surgical procedures. Chirurg 2001;72:660-666.

36 Sayfan J: Complications of Milligan-Morgan hemorrhoidectomy. Dig Surg 2001;18:131-133.

- 37 Sanchez-Mazzaferri F, Fadil-Iturralde J, Provenzal O, et al: Fournier's gangrene. Our experience over 10 years. A review of the literature. Arch Esp Urol 1999;52:721-727.

Presented at the Turkish National Surgery Congress, May 2008. 